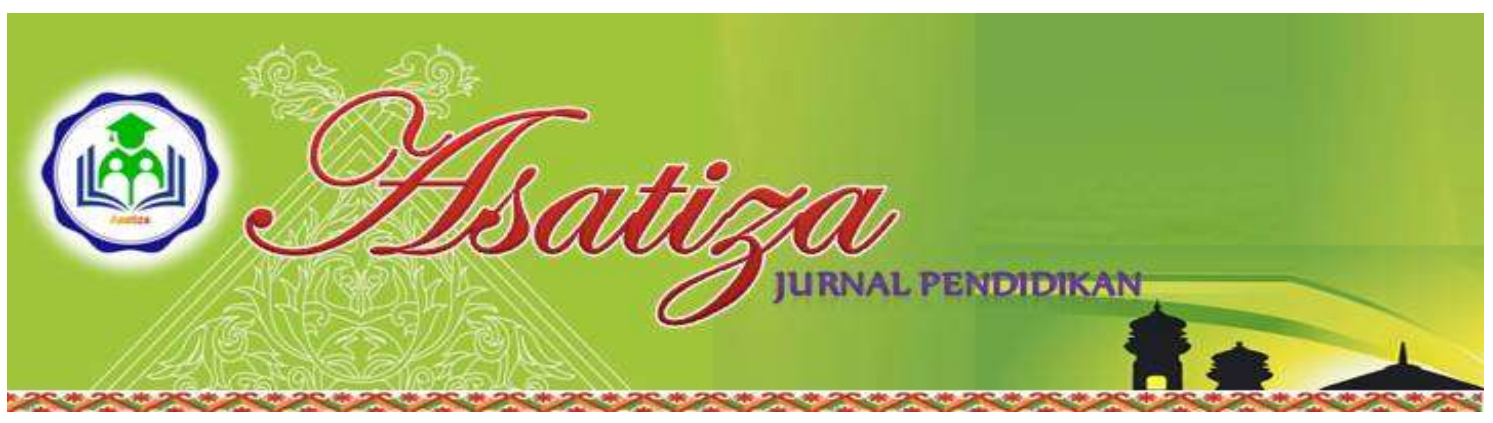

\title{
PENGARUH PENERAPAN KURIKULUM 2013 \\ TERHADAP KINERJA GURU PENDIDIKAN AGAMA ISLAM DI SEKOLAH DASAR SWASTA 021 PISIFERA PT. BUMI PALMA LESTARI PERSADARUMBAI JAYA KECAMATAN KEMPAS
}

Kamaliah Nur ${ }^{1}$

\author{
${ }^{1}$ Mahasiswi Prodi PAI STAI Auliurrasyidin Tembilahan, Indonesia
}

\begin{abstract}
Abstrak
Tujuan penelitian ini adalah untuk mengetahui penerapan Kurikulum 2013 guru Pendidikan Agama Islam kelas tinggi yaitu IV,V,VI. Untuk mengetahui kinerja guru Pendidikan Agama Islam kelas tinggi yaitu IV,V,VI. Untuk mengetahui pengaruh penerapan Kurikulum 2013 terhadap kinerja guru Pendidikan Agama Islam kelas tinggi yaitu IV,V,VI.

Populasi dalam penelitian ini adalah 1 orang guru Pendidikan Agama Islam. Data dalam penelitian ini dikumpulkan dengan menggunakan teknik observasi dan dokumentasi. Selanjutnya data yang terkumpul dianalisa dengan menggunakan rumus persentase dan regresi sederhana.

Hasil analisis data dapat disimpulkan bahwa: Penerapan Kurikulum 2013 Pendidikan Agama Islam, mencapai angka 68,06\% dan dikategorikan baik, karena angka 68,06\% terletak pada interval 61\% - 80\%. Kinerja guru Pendidikan Agama Islam, mencapai angka 72,22\% dan dikategorikan baik, karena angka 72,22\% terletak pada interval 61\% - 80\%.Terdapat pengaruh yang positif dan signifikan antara penerapan Kurikulum 2013 terhadap kinerja guru Pendidikan Agama Islam.
\end{abstract}

Kata Kunci:Penerapan Kurikulum 2013, Kinerja Guru.

\section{A. PENDAHULUAN}

\section{Latar belakang}

Guru merupakan komponen yang paling menentukan dalam sistem pendidikan secara keseluruhan, yang harus mendapat perhatian sentral, pertama, dan utama. Figur yang satu ini akan senantiasa menjadi sorotan strategis ketika berbicara masalah pendidikan, karena guru selalu terkait dengan komponen manapun dalam sistem pendidikan. Guru memegang peran utama dalam pembangunan pendidikan, khususnya yang diselenggarakan secara formal di sekolah. ${ }^{1}$

Sertifikat pendidik kepada seseorang yang telah menyelesaikan program pendidikan profesi pendidik dan lulus uji sertifikasi pendidik. Dalam hal ini, ujian sertifikasi pendidik dimaksudkan sebagai kontrol mutu hasil pendidikan, sehingga seseorang yang dinyatakan lulus dalam ujian sertifikasi pendidik diyakini

${ }^{1}$ E. Mulyasa, Standar Kompetensi dan Sertifikasi Guru, (Bandung: Remaja Rosdakarya, 2007), h.5. 
mampu melaksanakan tugas mendidik, mengajar, melatih, membimbing, dan menilai hasil belajar peserta didik. ${ }^{2}$

Undang-Undang Nomor 20 Tahun 2003 tentang sistem pendidikan nasional, Undang-Undang Nomor 14 Tahun 2005 tentang Guru dan Dosen, dan Peraturan Pemerintah Nomor 19 Tahun 2005 tentang Standar Nasional Pendidikan, mengutamakan bahwa guru wajib memiliki kualifikasi akademik, kompetensi dan sertifikat pendidik. Hal tersebut dimaksudkan untuk terwujudnya guru yang profesional yang mampu menjalankan profesinya sesuai dengan berbagai tuntutan tempat melaksanakan tugasnya. Dengan kata lain, usaha sertifikasi ini pada dasarnya adalah meningkatkan efektivitas pembelajaran yang dilakukan para guru pada tingkat satuan pendidikan atau sekolah. ${ }^{3}$

Indikator profesionalisme guru antara lain adalah guru tersebut mampu melaksanakan proses pembelajaran secara efektif. Sementara itu, pengelolaan proses pembelajaran itu sendiri pada dasarnya merupakan proses interaksi pedagogi antara guru, siswa, materi dan lingkunganya. Makin efektif proses interaksi pedagogik dilakukan guru, maka makin efektiflah proses pembelajaran yang dilakukan guru tersebut. ${ }^{4}$

Melalui pengamatan pendahuluan yang dilakukan penulis dengan cara observasi di Sekolah Dasar Swasta 021 Pisifera Rumbai Jaya Kecamatan Kempas, ditemukan kesenjangan antara

${ }^{2} I b i d$., h.4.

${ }^{3}$ Undang-Undang Nomor 20 Tahun 2003 tentang Sistem Pendidikan Nasional.

${ }^{4}$ E. Mulyasa, Op.Cit., h.13. penerapan Kurikulum 2013 dengan kinerja guru Pendidikan Agama Islam. Kesenjangan tersebut antara lain adalah sebagai berikut: Ada sebagian guru yang masih bingung dalam menerapkan Kurikulum 2013, dan tidak dapat menenangkan siswa yang ribut di dalam kelas, dan tidak memiliki perangkat pembelajaran secara lengkap.

\section{Konsep Kurikulum 2013}

Kurikulum 2013 ini dirancang dengan karakteristik sebagai berikut: ${ }^{5}$

a. Mengembangkan keseimbangan antara pengembangan sikap spiritual dan sosial, rasa ingin tahu, kreativitas, kerja sama dengan kemampuan intelektual dan psikomotorik;

b. Madrasah merupakan bagian dari masyarakat yang memberikan pengalaman belajar terencana di mana peserta didik menerapkan apa yang dipelajari di sekolah ke masyarakat dan memanfaatkan masyarakat sebagai sumber belajar;

c. Mengembangkan sikap, pengetahu an, dan keterampilan serta menerapkannya dalam berbagai situasi di madrasah dan masyarakat;

d. Memberi waktu yang cukup leluasa untuk mengembangkan berbagai sikap, pengetahuan, dan keterampilan;

e. Kompetensi dinyatakan dalam bentuk kompetensi inti kelas yang dirinci lebih lanjut dalam kompetensi dasar mata pelajaran;

f. Kompetensi inti kelas menjadi unsur pengorganisasian

(organizing

${ }^{5}$ Surat Keputusan Dirjen Pendidikan Islam No 2676 Th 2013 tentang Kurikulum 2013 Mata Pelajaran Pendidikan Agama Islam dan Bahasa Arab. 
elements) kompetensi dasar, di mana semua kompetensi dasar dan proses pembelajaran dikembangkan untuk mencapai kompetensi yang dinyata kan dalam kompetensi inti;

g. Kompetensi dasar dikembangkan didasarkan pada prinsip akumulatif, saling memperkuat (reinforced) dan memperkaya (enriched) antar mata pelajaran dan jenjang pendidikan (organisasi horizontal dan vertikal).

Kurikulum 2013 bertujuan untuk mempersiapkan manusia Indonesia agar memiliki kemampuan hidup sebagai pribadi dan warga negara yang beriman, produktif, kreatif, inovatif, dan afektif serta mampu berkontribusi pada kehidupan bermasyarakat, berbangsa, bernegara, dan peradaban dunia.

Standar kompetensi lulusan yang telah dirumuskan untuk jenjang satuan pendidikan Sekolah Dasar/Madrasah Ibtidaiyah digunakan untuk merumus kan kompetensi dasar yang diperlukan untuk mencapainya. Mengingat standar kompetensi lulusan masih harus dicapai pada akir jenjang sekolah dasar yang lamanya enam tahun, dalam usaha memudahkan operasional perumusan kompetensi dasar, diperlukan tujuan yang menyatakan capaian kompetensi pada tiap akhir jenjang kelas. Capaian kompetensi pada tiap akhir jenjang kelas dari kelas 1 sampai 6 ini disebut dengan kompetensi inti. ${ }^{6}$

Kompetensi inti adalah anak tangga yang harus dilalui siswa agar sampai pada kompetensi lulusan. Sebagai anak tangga menuju kompetensi lulusan

${ }^{6}$ Tim Penyusun Kemendikbud,Dokumen Kurikulum 2013 Kompetensi Dasar SD/MI, (Jakarta: Kemendikbud, 2013), h. 1. multidimensi, kompetensi inti juga memiliki sifat multidimensi. Untuk kemudahan operasionalnya, kompetensi lulusan pada ranah sikap dapat dibagi menjadi dua. Pertama, sikap spiritual yang terkait dengan tujuan pendidikan nasional dalam membentuk siswa yang beriman dan bertaqwa. Kedua, sikap sosial yang terkait dengan tujuan pendidikan nasional dalam membentuk siswa yang berakhlak mulia, mandiri, demokratis, dan bertanggung jawab.

Kompetensi inti bukan untuk diajarkan melainkan dibentuk melalui pembelajaran berbagai kompetensi dasar dari sejumlah mata pelajaran yang relevan. Kompetensi inti adalah pengikat berbagai kompetensi dasar yang harus dihasilkan dengan mempelajari tiap mata pelajaran, serta berfungsi sebagai integrator horisontal antar mata pelajaran. Dengan pengertian ini, kompetensi inti bebas dari mata pelajaran, karena tidak mewakili mata pelajaran tertentu. Kompetensi inti menyatakan kebutuhan kompetensi siswa, sedangkan mata pelajaran adalah pasokan kompetensi. Dengan demikian, kompetensi inti berfungsi sebagai unsur pengorganisasi an kompetensi dasar. ${ }^{7}$

Kompetensi inti merupakan pengikat untuk organisasi vertikal dan horisontal dari kompetensi dasar. Organisasi vertikal kompetensi dasar adalah keterkaitan kompetensi dasar satu kelas dengan kelas di atasnya, sehingga memenuhi prinsip belajar, yaitu terjadinya suatu akumulasi yang berkesinambungan antar kompetensi yang dipelajari siswa di sekolah dasar.

${ }^{7}$ Ibid., h. 1-2. 
Organisasi horisontal adalah keterkaitan antara kompetensi dasar satu mata pelajaran dengan kompetensi dasar dari mata pelajaran yang berbeda dalam satu kelas yang sama, sehingga terjadi proses saling memperkuat. Adapun rumusan kompetensi inti dalam menggunakan notasi adalah KI-1 untuk kompetensi inti sikap spiritual, KI-2 untuk kompetensi inti sikap sosial, KI-3 untuk kompetensi inti pengetahuan, dan KI-4 untuk kompetensi inti keterampilan. Untuk mendukung kompetensi inti ini, capaian pembelajaran mata pelajaran dapat diuraikan menjadi kompetensikompetensi dasar.

Sejalan dengan filosofi progresivisme dalam pendidikan, Kompetensi Inti ibaratnya adalah anak tangga yang harus ditapaki peserta didik untuk sampai pada kompetensi lulusan jenjang Madrasah Ibtidaiyah sampai pada jenjang Madrasah Aliyah. Kompetensi Inti (KI) meningkat seiring dengan meningkatnya usia peserta didik yang dinyatakan dengan meningkatnya kelas. Melalui Kompetensi Inti, integrasi vertikal berbagai kompetensi dasar (KD) pada kelas yang berbeda dapat dijaga. ${ }^{8}$

Secara rinci Kompetensi Inti yang diterapkan di Sekolah Dasar adalah:

\section{Tabel}

Kompetensi Inti di Sekolah Dasar

Pada Kurikulum 2013

\begin{tabular}{|l|c|c|}
\hline $\begin{array}{l}\text { Kompetensi } \\
\text { Inti Kelas I }\end{array}$ & $\begin{array}{c}\text { Kompetensi Inti } \\
\text { Kelas II }\end{array}$ & $\begin{array}{c}\text { Kompetensi Inti } \\
\text { Kelas III }\end{array}$ \\
\hline $\begin{array}{l}\text { 1. Menerima dan } \\
\text { menjalankan } \\
\text { ajaran agama } \\
\text { yang } \\
\text { dianutnya. }\end{array}$ & $\begin{array}{l}\text { 1. Menerima dan } \\
\text { menjalankan } \\
\text { ajaran agama } \\
\text { yang dianutnya. }\end{array}$ & $\begin{array}{l}\text { 1. Menerima dan } \\
\text { menjalankan } \\
\text { ajaran agama } \\
\text { yang dianutnya. }\end{array}$ \\
\hline
\end{tabular}

${ }^{8}$ Surat Keputusan Dirjen Pendidikan Islam No 2676 Th 2013 tentang Kurikulum 2013

\begin{tabular}{|c|c|c|}
\hline $\begin{array}{l}\text { 2. Memiliki } \\
\text { perilaku } \\
\text { jujur, } \\
\text { disiplin, } \\
\text { tanggung } \\
\text { jawab, } \\
\text { santun, } \\
\text { peduli, dan } \\
\text { percaya diri } \\
\text { dalam } \\
\text { berinteraksi } \\
\text { dengan } \\
\text { keluarga, } \\
\text { teman, dan } \\
\text { guru. }\end{array}$ & $\begin{array}{l}\text { 2. Menunjukkan } \\
\text { perilaku jujur, } \\
\text { disiplin, } \\
\text { tanggung } \\
\text { jawab, santun, } \\
\text { peduli, dan } \\
\text { percaya diri } \\
\text { dalam } \\
\text { berinteraksi } \\
\text { dengan } \\
\text { keluarga, } \\
\text { teman, } \\
\text { danguru. }\end{array}$ & $\begin{array}{l}\text { 2. Menunjukkan } \\
\text { perilaku jujur, } \\
\text { disiplin, } \\
\text { tanggung } \\
\text { jawab, santun, } \\
\text { peduli, dan } \\
\text { percaya diri } \\
\text { dalam } \\
\text { berinteraksi } \\
\text { dengan } \\
\text { keluarga, } \\
\text { teman, guru } \\
\text { dan } \\
\text { tetangganya. }\end{array}$ \\
\hline $\begin{array}{l}\text { 3. Memahami } \\
\text { pengetahuan } \\
\text { faktual } \\
\text { dengan cara } \\
\text { mengamati } \\
\text { (mendengar, } \\
\text { melihat, } \\
\text { membaca) } \\
\text { danmenanya } \\
\text { berdasarkan } \\
\text { rasa ingin } \\
\text { tahu tentang } \\
\text { dirinya, } \\
\text { makhluk } \\
\text { ciptaan Tuhan } \\
\text { dan } \\
\text { kegiatannya, } \\
\text { dan benda- } \\
\text { benda yang } \\
\text { dijumpainya } \\
\text { di rumah dan } \\
\text { di sekolah. }\end{array}$ & $\begin{array}{l}\text { 3. Memahami } \\
\text { pengetahuan } \\
\text { faktual dengan } \\
\text { cara mengamati } \\
\text { (mendengar, } \\
\text { melihat, } \\
\text { membaca) dan } \\
\text { menanya } \\
\text { berdasarkan rasa } \\
\text { ingin tahu } \\
\text { tentang dirinya, } \\
\text { makhluk ciptaan } \\
\text { Tuhan dan } \\
\text { kegiatannya, } \\
\text { dan benda- } \\
\text { benda yang } \\
\text { dijumpainya di } \\
\text { rumah dan di } \\
\text { sekolah. }\end{array}$ & $\begin{array}{l}\text { Memahami } \\
\text { pengetahuan } \\
\text { faktual dengan } \\
\text { cara mengamati } \\
\text { (mendengar, } \\
\text { melihat, } \\
\text { membaca) } \\
\text { danmenanya } \\
\text { berdasarkan } \\
\text { rasa ingin tahu } \\
\text { tentang dirinya, } \\
\text { makhluk ciptaan } \\
\text { Tuhan dan } \\
\text { kegiatannya, } \\
\text { dan benda- } \\
\text { benda yang } \\
\text { dijumpainya di } \\
\text { rumah dan di } \\
\text { sekolah. }\end{array}$ \\
\hline 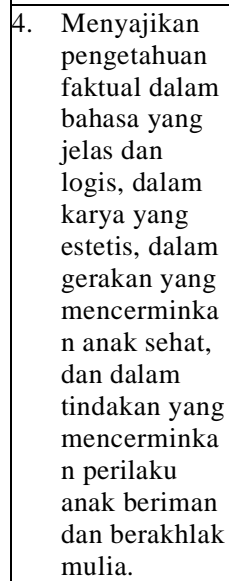 & 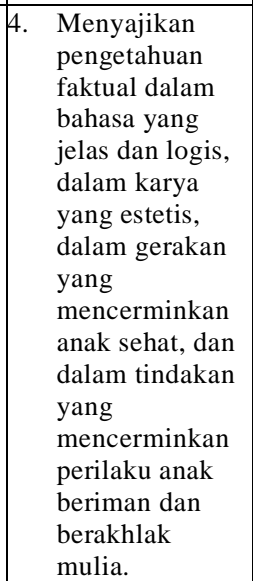 & 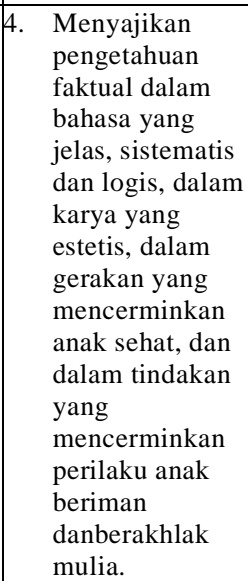 \\
\hline
\end{tabular}

\begin{tabular}{|c|c|c|}
\hline $\begin{array}{c}\text { Kompetensi Inti } \\
\text { Kelas IV }\end{array}$ & $\begin{array}{c}\text { Kompetensi Inti } \\
\text { Kelas V }\end{array}$ & $\begin{array}{c}\text { Kompetensi Inti } \\
\text { Kelas VI }\end{array}$ \\
\hline $\begin{array}{l}\text { 1. Menerima, } \\
\text { menjalankan } \\
\text {, dan } \\
\text { menghargai } \\
\text { ajaran } \\
\text { agama yang } \\
\text { dianutnya }\end{array}$ & $\begin{array}{l}\text { 1. Menerima, } \\
\text { menjalankan, } \\
\text { dan menghargai } \\
\text { ajaran agama } \\
\text { yang dianutnya. }\end{array}$ & $\begin{array}{l}\text { 1. Menerima, } \\
\text { menjalankan } \\
\text {, dan } \\
\text { menghargai } \\
\text { ajaran agama } \\
\text { yang } \\
\text { dianutnya. }\end{array}$ \\
\hline $\begin{array}{l}\text { 2. Menunjuk } \\
\text { kan } \\
\text { perilaku } \\
\text { jujur, }\end{array}$ & $\begin{array}{l}\text { Menunjukkan } \\
\text { perilaku jujur, } \\
\text { disiplin, } \\
\text { tanggung }\end{array}$ & $\begin{array}{l}\text { 2. Menunjukka } \\
\text { n perilaku } \\
\text { jujur, } \\
\text { disiplin, }\end{array}$ \\
\hline
\end{tabular}




\begin{tabular}{|c|c|c|}
\hline $\begin{array}{l}\text { disiplin, } \\
\text { tanggung } \\
\text { jawab, } \\
\text { santun, } \\
\text { peduli, dan } \\
\text { percaya } \\
\text { diri dalam } \\
\text { berinteraks } \\
\text { i dengan } \\
\text { keluarga, } \\
\text { teman, } \\
\text { guru, dan } \\
\text { tetangga } \\
\text { nya. } \\
\end{array}$ & $\begin{array}{l}\text { jawab, santun, } \\
\text { peduli, dan } \\
\text { percaya diri } \\
\text { dalam } \\
\text { berinteraksi } \\
\text { dengan } \\
\text { keluarga, } \\
\text { teman, guru, } \\
\text { dan } \\
\text { tetangganya } \\
\text { serta cinta } \\
\text { tanah air. }\end{array}$ & $\begin{array}{l}\text { tanggung } \\
\text { jawab, } \\
\text { santun, } \\
\text { peduli, dan } \\
\text { percaya diri } \\
\text { dalam } \\
\text { berinteraksi } \\
\text { dengan } \\
\text { keluarga, } \\
\text { teman, guru, } \\
\text { dan } \\
\text { tetangganya } \\
\text { sertacinta } \\
\text { tanah air. }\end{array}$ \\
\hline $\begin{array}{l}\text { 3. Memahami } \\
\text { pengetahuan } \\
\text { faktual } \\
\text { dengan cara } \\
\text { mengamati } \\
\text { dan } \\
\text { menanya } \\
\text { berdasarkan } \\
\text { rasa ingin } \\
\text { tahu tentang } \\
\text { dirinya, } \\
\text { makhluk } \\
\text { ciptaan } \\
\text { Tuhan dan } \\
\text { kegiatannya, } \\
\text { dan benda- } \\
\text { benda yang } \\
\text { dijumpainya } \\
\text { di rumah, di } \\
\text { sekolah dan } \\
\text { tempat } \\
\text { bermain. }\end{array}$ & $\begin{array}{l}\text { 3. Memahami } \\
\text { pengetahuan } \\
\text { faktual dan } \\
\text { konseptualden } \\
\text { gan cara } \\
\text { mengamati } \\
\text { dan mencoba } \\
\text { berdasarkan } \\
\text { rasa ingin tahu } \\
\text { tentang } \\
\text { dirinya, } \\
\text { makhluk } \\
\text { ciptaan Tuhan } \\
\text { dan } \\
\text { kegiatannya, } \\
\text { dan benda- } \\
\text { benda yang } \\
\text { dijumpainya di } \\
\text { rumah, di } \\
\text { sekolah dan } \\
\text { tempat } \\
\text { bermain. }\end{array}$ & $\begin{array}{l}\text { 3. Memahami } \\
\text { pengetahuan } \\
\text { faktual dan } \\
\text { konseptuald } \\
\text { engan cara } \\
\text { mengamati } \\
\text { dan } \\
\text { menanya } \\
\text { berdasarkan } \\
\text { rasa ingin } \\
\text { tahu tentang } \\
\text { dirinya, } \\
\text { makhluk } \\
\text { ciptaan } \\
\text { Tuhan dan } \\
\text { kegiatannya, } \\
\text { dan benda- } \\
\text { benda yang } \\
\text { dijumpainya } \\
\text { di rumah, di } \\
\text { sekolah dan } \\
\text { tempat } \\
\text { bermain. }\end{array}$ \\
\hline $\begin{array}{l}\text { 4. Menyajikan } \\
\text { pengetahuan } \\
\text { faktual } \\
\text { dalam } \\
\text { bahasa yang } \\
\text { jelas, } \\
\text { sistematis } \\
\text { dan logis, } \\
\text { dalam karya } \\
\text { yang estetis, } \\
\text { dalam } \\
\text { gerakan } \\
\text { yang } \\
\text { mencermink } \\
\text { an anak } \\
\text { sehat, dan } \\
\text { dalam } \\
\text { tindakan } \\
\text { yang } \\
\text { mencermink } \\
\text { an perilaku } \\
\text { anak } \\
\text { beriman dan } \\
\text { berakhlak } \\
\text { mulia. }\end{array}$ & $\begin{array}{l}\text { 4. Menyajikan } \\
\text { pengetahuan } \\
\text { faktual dan } \\
\text { konseptual } \\
\text { dalam bahasa } \\
\text { yang jelas, } \\
\text { sistematis, } \\
\text { logis dan kritis } \\
\text { dalam karya } \\
\text { yang estetis, } \\
\text { dalam gerakan } \\
\text { yang } \\
\text { mencerminkan } \\
\text { anak sehat, } \\
\text { dan dalam } \\
\text { tindakan yang } \\
\text { mencerminkan } \\
\text { perilaku anak } \\
\text { beriman dan } \\
\text { berakhlak } \\
\text { mulia. }\end{array}$ & $\begin{array}{l}\text { 4. Menyajikan } \\
\text { pengetahuan } \\
\text { faktual dan } \\
\text { konseptual } \\
\text { dlm bahasa } \\
\text { yg jelas, sis } \\
\text { tematis, lo } \\
\text { gis dan kri } \\
\text { tis, dalam } \\
\text { karya yg } \\
\text { estetis, dlm } \\
\text { gerakan yg } \\
\text { mencermink } \\
\text { an anak } \\
\text { sehat, dan } \\
\text { dlm } \\
\text { tindakan yg } \\
\text { mencermink } \\
\text { an perilaku } \\
\text { anak } \\
\text { beriman dan } \\
\text { berakhlak } \\
\text { mulia. }\end{array}$ \\
\hline
\end{tabular}

Sumber Data: Surat Keputusan Dirjen Pendidikan Islam No 2676 Th 2013 tentang Kurikulum 2013.

Kompetensi Dasar dibutuhkan untuk mendukung pencapaian kompetensi lulusan melalui Kompetensi Inti. Selain itu, Kompetensi Dasar diorganisir ke dalam berbagai mata pelajaran yang pada gilirannya berfungsi sebagai sumber kompetensi. Mata pelajaran yang dipergunakan sebagai sumber kompetensi tersebut harus mengacu pada ketentuan yang tercantum pada Undang-undang Sistem Pendidikan Nasional Nomor 20 Tahun 2003, khususnya ketentuan pada Pasal 37.

Selain jenis mata pelajaran yang diperlukan untuk membentuk kompetensi, juga diperlukan beban belajar per minggu dan per semester atau per tahun. Beban belajar ini kemudian didistribusikan ke berbagai mata pelajaran sesuai dengan tuntutan kompetensi yang diharapkan dapat dihasilkan oleh tiap mata pelajaran.

Tabel

Beban Belajar Pada Kurikulum 2013 di Sekolah Dasar

\begin{tabular}{|c|l|c|c|c|c|c|c|c|}
\hline \multirow{2}{*}{ Mata Pelajaran } & \multicolumn{7}{|c|}{ Alokasi Waktu Belajar } \\
\cline { 2 - 8 } & I & \multicolumn{1}{|c|}{ II } & \multicolumn{1}{|c|}{ III } & IV & V & VI \\
\hline 1 & $\begin{array}{l}\text { Pendidikan } \\
\text { Agama Islam }\end{array}$ & 4 & 4 & 4 & 4 & 4 & 4 \\
\hline 2 & $\begin{array}{l}\text { Pendidikan } \\
\text { Kancasila dan } \\
\text { Kelomarga } \\
\text { negaraan }\end{array}$ & 5 & 5 & 6 & 5 & 5 & 5 \\
\hline 3 & $\begin{array}{l}\text { Bahasa } \\
\text { Indonesia }\end{array}$ & 8 & 9 & 10 & 7 & 7 & 7 \\
\hline 4 & Bahasa Arab & 2 & 2 & 2 & 2 & 2 & 2 \\
\hline 5 & Matematika & 5 & 6 & 6 & 6 & 6 & 6 \\
\hline 6 & $\begin{array}{l}\text { Ilmu } \\
\text { Pengetahuan } \\
\text { Alam }\end{array}$ & - & - & - & 3 & 3 & 3 \\
\hline 7 & $\begin{array}{l}\text { Ilmu } \\
\text { Pengetahuan } \\
\text { Sosial }\end{array}$ & - & - & - & 3 & 3 & 3 \\
\hline Kelompok B & $\begin{array}{l}\text { Seni Budaya } \\
\text { dan Prakarya }\end{array}$ & 4 & 4 & 4 & 5 & 5 & 5 \\
\hline 2 & Pendidikan & 4 & 4 & 4 & 4 & 4 & 4 \\
\hline
\end{tabular}




\begin{tabular}{|c|c|c|c|c|c|c|c|}
\hline$\cdot \begin{array}{l}\text { Jasmani, Olah } \\
\text { Raga, dan } \\
\text { Kesehatan }\end{array}$ & & & & & & \\
\hline $\begin{array}{l}\text { Jumlah Alokasi } \\
\text { Waktu Per Minggu }\end{array}$ & $\mathbf{3 0}$ & $\mathbf{3 2}$ & $\mathbf{3 4}$ & $\mathbf{3 6}$ & $\mathbf{3 6}$ & $\mathbf{3 6}$ \\
\hline
\end{tabular}

Sumber Data: Surat Keputusan Dirjen Pendidikan Islam No 2676 Th 2013 tentang Kurikulum 2013

\section{Penerapan KegiatanPembelajaran}

\section{Pada Kurikulum 2013}

Guru perlu menyusun rencana pelaksanaan pembelajaran. Rencana pembelajaran ini merupakan realisasi dari pengalaman belajar siswa yang telah ditetapkan dalam silabus pembelajaran. Adapun komponen RPP terdiri atas: ${ }^{9}$

a. Identitas sekolah yaitu nama satuan pendidikan

b. Identitas mata pelajaran atau tema/ subtema;

c. Kelas/semester;

d. Materi pokok;

e. Alokasi waktu ditentukan sesuai dengan keperluan untuk pencapaian KD dan beban belajar dengan mempertimbangkan jumlah jam pelajaran yang tersedia dalam silabus dan KD yang harus dicapai;

f. Tujuan pembelajaran yang dirumus kan berdasarkan KD, dengan menggunakan kata kerja operasional yang dapat diamati dan diukur, yang mencakup sikap, pengetahuan, dan keterampilan;

g. Kompetensi dasar dan indikator pencapaian kompetensi;

h. Materi pembelajaran, memuat fakta, konsep, prinsip, dan prosedur yang relevan, dan ditulis dalam bentuk butir-butir sesuai dengan rumusan indikator ketercapaian kompetensi;

${ }^{9}$ Surat Keputusan Dirjen Pendidikan Islam No 2676 Th 2013 tentang Kurikulum 2013. i. Metode pembelajaran, digunakan oleh pendidik untuk mewujudkan suasana belajar dan proses pembelajaran agar peserta didik mencapai KD yang disesuaikan dengan karakteristik peserta didik dan KD yang akan dicapai;

j. Media pembelajaran, berupa alat bantu proses pembelajaran untuk menyampaikan materi pelajaran;

k. Sumber belajar, dapat berupa buku, media cetak dan elektronik, alam sekitar, atau sumber belajar lain yang relevan;

1. Langkah-langkah pembelajaran dilakukan melalui tahapan pendahuluan, inti, dan penutup; dan

m. Penilaian hasil pembelajaran.

Langkah-Langkah Pengembangan RPP pada Kurikulum 2013 disusun secara tematik, meliputi:

a. Mengkaji Silabus

Secara umum, untuk setiap materi pokok pada setiap silabus terdapat 4KD sesuai dengan aspek KI (sikap kepada Tuhan, sikap diri dan terhadap lingkungan, pengetahuan, dan keterampilan). Untuk mencapai $4 \mathrm{KD}$ tersebut, di dalam silabus dirumuskan kegiatan peserta didik secara umum dalam pembelajaran berdasarkan standar proses. Kegiatan peserta didik ini merupa kan rincian dari eksplorasi, elaborasi, dan konfirmasi, yakni: mengamati, menanya, mengumpul kan informasi, mengolah dan mengkomunikasikan. Kegiatan ini lah yang harus dirinci lebih lanjut di dalam RPP, dalam bentuk langkahlangkah yang dilakukan guru dalam pembelajaran, yang membuat 
peserta didik aktif belajar. Pengkajian terhadap silabus juga meliputi perumusan indikator $\mathrm{KD}$ dan penilaiannya.

b. Mengidentifikasi Materi Pembelajaran

Mengidentifikasi materi pembelajaran yang menunjang pencapaian KD dengan mempertimbangkan: Potensi peserta didik; Relevansi dengan karakteristik daerah, Tingkat perkembangan fisik, intelektual, emosional, sosial, dan spritual peserta didik; Kebermanfaatan bagi peserta didik; Struktur keilmuan; Aktualitas, kedalaman, dan keluasan materi pembelajaran; Relevansi dengan kebutuhan peserta didik dan tuntutan lingkungan; dan Alokasi waktu.

c. MenentukanTujuan

Tujuan dapat diorganisasikan mencakup seluruh KD atau diorganisasikan untuk setiap pertemuan. Tujuan mengacu pada indikator, paling tidak mengandung dua aspek: Audience (peserta didik) dan Behavior (aspek kemampuan).

d. Mengembangkan Kegiatan Pembelajaran

Kegiatan pembelajaran dirancang untuk memberikan pengalaman belajar yang melibatkan proses mental dan fisik melalui interaksi antar peserta didik, peserta didik dengan guru, lingkungan, dan sumber belajar lainnya dalam rangka pencapaian KD. Pengalaman belajar yang dimaksud dapat terwujud melalui penggunaan pendekatan pembelajaran yang bervariasi dan berpusat pada peserta didik. Pengalaman belajar memuat kecakapan hidup yang perlu dikuasai peserta didik. Hal-hal yang harus diperhatikan dalam mengembangkan kegiatan pembelajaran adalah sebagai berikut: Kegiatan pembelajaran disusun untuk memberikan bantuan kepada para pendidik, khususnya guru, agar dapat melaksanakan proses pembelajaran secara profesional, Kegiatan pembelajaran memuat rangkaian kegiatan manajerial yang dilakukan guru, agar peserta didik dapat melakukan kegiatan seperti di silabus, Kegiatan pembelajaran untuk setiap pertemuan merupakan skenario langkah-langkah guru dalam membuat peserta didik aktif belajar. Kegiatan ini diorganisasi kan menjadi kegiatan: Pendahuluan, Inti, dan Penutup. Kegiatan inti dijabarkan lebih lanjut menjadi rincian dari kegiatan eksplorasi, elaborasi, dan konfirmasi, yakni: mengamati, menanya, mengum pulkan informasi, mengasosiasi kan, dan mengkomunikasikan. Untuk pembelajaran yang bertujuan menguasai prosedur untuk melaku kan sesuatu, kegiatan pembelajaran dapat berupa pemodelan/demonstrasi oleh guru atau ahli, peniruan oleh peserta didik, pengecekan dan pemberian umpan balik oleh guru, dan pelatihan lanjutan.

e. Penjabaran

Jenis Penilaian di dalam silabus telah ditentukan jenis penilaian nya. Penilaian pencapaian KD peserta didik dilakukan berdasar kan 
indikator. Penilaian dilakukan dengan menggunakan tes dan nontes dalam bentuk tertulis maupun lisan, pengamatan kinerja, pengukuran sikap, penilaian hasil karya berupa tugas, proyek dan/atau produk, penggunaan portofolio, dan penilaian diri. Oleh karena pada setiap pembelajaran peserta didik didorong untuk menghasilkan karya, maka penyajian portofolio merupakan cara penilaian yang harus dilakukan untuk jenjang pendidikan dasar dan menengah. Penilaian merupakan serangkaian kegiatan untuk memperoleh, menganalisis, dan menafsirkan data tentang proses dan hasil belajar peserta didik yang dilakukan secara sistematis dan berkesinambungan, sehingga menjadi informasi yang bermakna dalam pengambilan keputusan. Hal-hal yang perlu diperhatikan dalam merancang penilaian yaitu sebagai berikut: Penilaian diarahkan untuk mengukur pencapaian kompetensi yaitu KD-KD pada KI-3 danKI-4, Penilaian menggunakan acuan kriteria; yaitu berdasarkan apa yang bisa dilakukan peserta didik setelah mengikuti proses pembelajaran, dan bukan untuk menentukan posisi seseorang terhadap kelompoknya, Sistem yang direncanakan adalah sistem penilaian yang berkelanjutan. Berkelanjutan dalam arti semua indikator ditagih, kemudian hasil nya dianalisis untuk menentukan KD yang telah dimiliki dan yang belum, serta untuk mengetahui kesulitan peserta didik, Hasil penilaian dianalisis untuk menentu kan tindak lanjut. Tindak lanjut berupa perbaikan proses pembelajar an berikutnya, program remedi bagi peserta didik yang pencapaian kompetensinya di bawah ketuntas an, dan program pengayaan bagi peserta didik yang telah memenuhi ketuntasan, Sistem penilaian harus disesuaikan dengan pengalaman belajar yang ditempuh dalam proses pembelajaran. Misalnya, jika pembelajaran menggunakan pendekatan tugas observasi lapangan maka evaluasi harus diberikan baik pada proses misalnya teknik wawancara, maupun produk berupa hasil melakukan observasi lapangan.

f. Menentukan AlokasiWaktu Penentuan alokasi waktu pada setiap KD didasarkan pada jumlah minggu efektif dan alokasi waktu matapelajaran per minggu dengan mempertimbang kan jumlah KD, keluasan, kedalaman, tingkat kesulitan, dan tingkat kepentingan KD. Alokasi waktu yang dicantum kan dalam silabus merupakan perkiraan waktu rerata untuk menguasai KD yang dibutuhkan oleh peserta didik yang beragam. Oleh karena itu, alokasi tersebut dirinci dan disesuaikan lagi di RPP.

g. Menentukan Sumber Belajar

Sumber belajar adalah rujukan, objek dan / atau bahan yang digunakan untuk kegiatan pembelajaran, yang berupa media cetak dan elektronik, narasumber, serta lingkungan fisik, alam, sosial, dan budaya. 
Selanjutnya Trianto menjelaskan bahwa rancangan strategi pembelajaran yang diterapkan dalam pembelajaran tematik pada dasarnya terbagi atas empat komponen utama, yaitu waktu, urutan kegiatan pembelajaran, metode, dan media/bahan.

a. Waktu. Jumlah waktu yang dibutuhkan untuk mengajar, terbatas kepada waktu yang digunakan pengajar dalam pertemuan dengan siswa. Waktu untuk siswa adalah jumlah waktu yang digunakan dalam pertemuan dengan pengajar ditambah dengan waktu yang digunakan untuk melaksanakan tugas yang sehubungan dengan mata pelajaran di luar pertemuan dengan pengajar. Menghitung jumlah waktu yang digunakan oleh pengajar penting artinya bagi pengajar sendiri dalam mengelola kegiatan pembelajaran. Ia harus dapat membagi waktu untuk setiap langkah dalam pendahuluan, penyajian, dan penutup.

b. Urutan kegiatan pembelajaran. Kegiatan pembelajaran terdiri atas komponen pendahuluan, inti/ penyajian, dan penutup. Setiap sub komponen tersebut terdiri atas beberapa langkah sebagaimana diuraikan pada tahap pelaksanaan pembelajaran tematik di atas. Sub komponen dari masing-masing urutan komponen kegiatan pembelajaran bersifat fleksibel pada setiap tema yang disajikan dalam pembelajaran tematik. Sub komponen ini tergantung pada waktu, kondisi kelas, dan lingkungan kelas, tema dan tujuan yang akan disajikan dalam kegiatan pembelajaran tematik. ${ }^{10}$

c. Metode. Salah satu komponen utama pada strategi pembelajaran di luar urutan kegiatan pembelajaran adalah metode pembelajaran. Metode pembelajaran berfungsi sebagai cara dalam menyajikan (menguraikan, memberi contoh, dan memberi latihan) isi pelajaran kepada siswa untuk mencapai tujuan tertentu. Strategi pembelajaran tematik yang dirancang pengembang harus memilih metode yang sesuai untuk setiap tujuan pembelajaran yang ingin dicapai, karena tidak semua metode pembelajaran sesuai untuk digunakan dalam mencapai tujuan pembelajaran tertentu, sesuai untuk semua tingkatan kelas (terutama di kelas awal sekolah dasar), sesuai untuk setiap tema yang disajikan dalam pembelajaran tematik. Beberapa metode yang dapat digunakan dalam pembelajaran tematik, antara lain: ceramah, demonstrasi, penampilan, latihan, simulasi, bermain peran, dan sebagainya. ${ }^{11}$

d. Media/bahan pembelajaran. Media adalah alat yang digunakan untuk menyalurkan pesan atau informasi dari pengirim kepada penerima pesan. Pengirim dan penerima pesan itu dapat berbentuk orang atau lembaga, sedangkan media tersebut berupa alatalat elektronik, gambar, buku, benda nyata, dan sebagainya. Media yang digunakan dalam pembelajaran dapat

${ }^{10}$ Ibid., h.186.

${ }^{11}$ Syaiful Bahri Djamarah dan Aswan Zain, Strategi Belajar Mengajar, (Jakarta: Rineka Cipta, 2006), h. 82. 
beraneka ragam. Pengembang pembelajaran dapat memilih salah satu atau beberapa diantaranya untuk digunakan dalam menyusun strategi pembelajarannya. ${ }^{12}$

Sedangkan menurut Lukmanul Hakim, langkah - langkah perencanaan pembelajaran tematik adalah:

a. Mempelajari butir - butir pembelajar an dalam garis-garis besar progam pembelajaran GBPP).

b. Menyusun sendiri butir-butir pembelajaran, apa saja yang dapat dipadu dalam unit tematis tertentu.

c. Menetapkan kompetensi dasar dan merumuskan indikator pembelajaran nya.

d. Mengidentifikasi keselarasan hubungan kompetensi dasar dengan butir-butir indikator hasil belajar dari antar topik pembelajaran.

e. Menentukan tema dan teks yang akan dijadikan landasan pembelajar an

f. Menentukan skenario pembelajaran nya. Skenario pembelajaran tematik harus menggambarkan:

1) prosedur kegiatan pembelajaran.

2) kegiatan yang dilakukan guru dalam menciptakan, mengendali kan dan menilai proses pembelajaran.

3) bentuk interaksi antara guru dengan siswa dan siswa dengan siswa. ${ }^{13}$

Strategi pembelajaran tematik lebih mengutamakan pengalaman belajar siswa secara langsung dan menghubungkan dengan konsep lain

${ }^{12} I b i d$. .h.187.

${ }^{13}$ Lukmanul Hakim, Perencanaan dan Pembelajaran, (Bandung: Wacana Prima, 2008),h. 214. yang sudah dipahami sesuai dengan kebutuhan dan perkembangan siswa.

Pembelajaran dalam kuri- kulum 2013 menurut Ridwan Abdullah Sani dapat digambarkan sebagai berikut:

Gambar

Proses Pembelajaran dalam kurikulum 2013

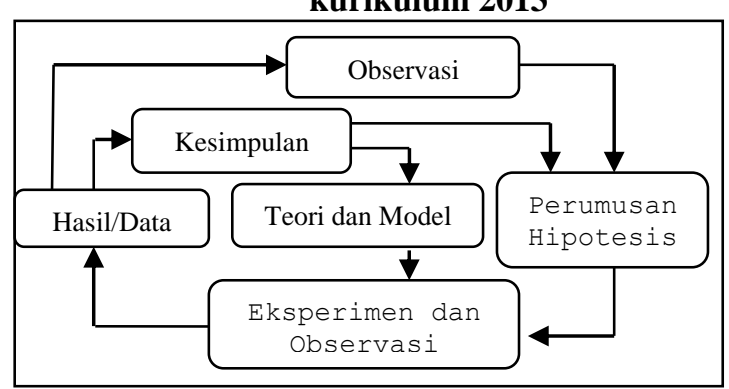

Uraian di atas menggambar kan dengan jelas penerapan kurikulum 2013 dalam kegiatan pembelajaran.

\section{Kinerja Guru}

Mendefinisikan kinerja guru, Robert Bacal sebagaimana yang dikutip oleh Martinis Yamin dan Maisah menyebutkan sebagai "proses komunikasi yang berlangsung terus menerus, yang dilaksanakan kemitraan, antara seorang guru dengan siswa". ${ }^{14}$

Proses komunikasi yang baik antara kepala sekolah dengan guru, dan guru dengan siswa dalam proses pembelajaran dapat lebih mempercepatkan pemaham an siswa terhadap materi yang disampaikan oleh guru, dan ini merupakan suatu sistem kinerja yang memberi nilai tambah bagi sekolah dalam rangka meningkatkan kualitas siswa dalam belajar. Menurut A. Tabrani Rusyan kinerja guru adalah:

"Hasil yang dicapai oleh guru dalam melaksanakan tugas-tugas yang dibebankan kepadanya yang

${ }^{14}$ Martinis Yamin dan Maisah, Standarisasi Kinerja Guru, (Jakarta: Gaung Persada Press, 2010), h. 129. 
didasarkan atas kecakapan, pengalaman dan kesungguhan, serta penggunaan waktu". ${ }^{15}$

Melihat definisi ini maka dengan kata lain kinerja guru dapat dipahami sebagai etos kerja yang berujung pada produktivitas kerja dan pembelajaran. Kinerja Guru dalam Pembelajaran Produktivitas kerja dalam proses pembelajaran dapat dilihat dengan cara sebagai berikut:

a. Meningkatkan mutu pembelajaran sesuai dengan kebutuhan dan tuntutan peserta didik melalui kriteria ketuntasan minimal.

b. Menggunakan alat dan media pendidikan dalam proses pembelajaran.

c. Mendorong lahirnya "Sumber Daya Manusia" yang berkualitas melalui proses pembelajaran yang efektif dan efisien.

d. Memotivasi peserta didik menghargai dan mengejar kualitas yang tinggi melalui proses pembelajaran.

e. Meningkatkan perhatian kepada peserta didik yang berbakat.

f. Meningkatkan proses pembelajaran sesuai dengan kebutuhan globalisasi melalui pengajaran keterampilan.

g. Mengubah peserta didik untuk berorientasi kepada kekaryaan bukan kepada ijazah.

h. Membudayakan sikap kritis dan terbuka sebagai syarat tumbuhnya pola pikir siswa yang lebih demokratis. i. Membudayakan nilai-nilai yang mencintai kualitas kepada peserta didik.

j. Membudayakan sikap kerja keras, produktif, dan disiplin. ${ }^{16}$

Selanjutnya Rusman merinci kinerja guru sebagai berikut :

a. Perencanaan guru dalam program kegiatan pembelajaran adalah:

1) Mempersiapkan perencanaan dalam pembelajaran.

2) Mengelola program kegiatan pembelajaran.

3) Menguasai bahan pembelajar an.

b. Pelaksanaan kegiatan pembelajar an

1) Mengelola kelas.

2) Menciptakan suasana kondusif di dalam kelas.

3) Memupuk kerja sama dan disiplin kepada siswa.

4) Menggunakan media pembelajaran.

5) Menggunakan sumber-sumber belajar lain yang relevan kepada siswa.

6) Menggunakan metode pembelajaran sesuai dengan materi yang dsampaikan.

7) Melaksanakan proses pembelajaran.

c. Evaluasi dalam kegiatan

1) Penilaian relevan dengan pembelajaran.

2) Menggunakan bentuk dan jenis ragam penilaian.

3) Penilaian yang diberikan sesuai dengan yang dituangkan dalam RPP. ${ }^{17}$

\footnotetext{
${ }^{16}$ Wardiman Djoyonegoro, Peningkatan kualitas Melalui Pendidikan dan kebudayaan, (Jakarta: Depdikbud, 2000), h. 84.

${ }^{17}$ Ibid., h. 75-80.
} 
Lebih lanjut dijelaskan bahwa bentuk kongkrit dari kinerja guru antara lain sebagai berikut:

a. Berkualifikasi pendidikan yang memadai (sesuai dengan jenjang pendidikan di mana tenaga pengajar mengajar).

b. Mempunyai visi dan misi sebagai tenaga pengajar

c. Mampu mentransferkan ilmunya kepada peserta didik.

d. Mampu merubah sikap atau mempengaruhi dan memotivasi peserta didik.

e. Sesuai dengan bidang/ kompetensi nya.

f. Mampu menguasai kelas.

g. Menguasai materi pelajaran.

h. Menggunakan metode pembelajar an yang bervariasi.

i. Berwawasan luas.

j. Berkomunikasi dengan baik (bahasa baku, logat, dan ekspresi yang tepat.

Perihal tenaga pengajar dengan kinerjanya adalah menyangkut seluruh aktivitas yang ditunjukkan oleh tenaga pengajar dalam tanggung jawabnya sebagai orang yang mengemban suatu amanat dan tanggung jawab untuk mendidik, mengajar, membimbing, mengarahkan, dan memandu peserta didik dalam rangka menggiring perkembangan peserta didik ke arah kedewasaan mental spiritual maupun fisik biologis.

Semakin tinggi angka kriteria ketuntasan minimal yang ditetapkan guru, maka semakin tinggi pulalah ketercapaian siswa dalam pembelajaran. Oleh karena itu, melalui penetapan angka kriteria ketuntasan minimal kinerja guru dapat diukur. Dengan menggunakan alat peraga dan media yang sesuai dalam proses pembelajaran, guru juga telah menunjukkan kinerja yang baik.

Salah satu usaha guru lainnya untuk meningkatkan kualitas pendidikan, yang berpangkal pada kinerja guru itu sendiri adalah dengan berupaya menghubungkan materi pelajaran terhadap situasi yang nyata, yaitu apa yang ada disekitar siswa. Dalam hal ini guru dapat memanfaatkan lingkungan sekitar untuk mendukung pelaksanaan pembelajaran, sehingga pembelajaran akan menjadi lebih bermakna bagi siswa.

Untuk menumbuhkan motivasi belajar pada diri siswa, guru dapat memberikan hadiah kepada siswa yang berprestasi.Selain itu guru juga harus memberikan bimbingan dan arahan kepada siswa sesuai dengan bakat yang dimiliki siswa.Untuk memberikan semangat belajar, guru juga dapat memanfaatkan teknologi canggih, seperti komputer, dan internet.

Proses pembelajaran dapat berkembang sesuai dengan tuntutan bila didukung oleh partisipasi guru yang memiliki jasmaniah dan rohaniah tidak secara otomatis dapat dimiliki guru melainkan berdasarkan upaya dilakukan melalui produktivitas kerja. Sebab setiap guru dengan adanya era globalisasi menunjukkan akan kepentingan produktivitas kerja dalam rangka meningkatkan kualitas sumber daya manusia sehingga memiliki kemampuan profesional dalam bekerja. 


\section{B. METODOLOGI}

Jenis penelitian yang diterapkan dalam penelitian ini adalah penelitian kuantitatif. Subjek dalam penelitian ini adalah guru di Sekolah Dasar Swasta 021 Pisifera PT.Bumi Palma Lestari Persada Rumbai Jaya Kecamatan Kempas. Sedangkan objek dalam penelitian ini adalah pengaruh penerapan Kurikulum 2013 terhadap kinerja guru Pendidikan Agama Islam. Populasi dalam penelitian ini adalah 1 orang guru Pendidikan Agama Islam. Data dalam penelitian ini dikumpulkan dengan menggunakan teknik observasi dan dokumentasi. Selanjutnya data yang terkumpul dianalisa dengan mengguna kan rumus persentase dan regresi sederhana. Data yang sudah terkumpul, penulis kualifikasikan atau tuangkan kedalam bentuk angka-angka. Sehingga data tersebut bersifat kuantitatif. Untuk selanjutnya dianalisa dan diinterpretasi kan secara deskriptif. Pengalihan data kedalam bentuk kuantitatif ini ditempuh dengan menggunakan rumus analisis regresi, yaitu: ${ }^{18}$

Persamaan regresi dirumuskan:

$\hat{\mathrm{Y}}=\alpha+\mathrm{bX}$

Dimana:

$\hat{\mathrm{Y}}=$ (baca $\mathrm{Y}$ topi)

Subjek variable terikat yang diproyeksikan. $\mathrm{X}=$ Variabel bebas yang mempunyai nilai tertentu untuk diprediksikan.

$\alpha=$ Nilai konstanta harga $Y$ jika $X=0$

$\mathrm{b}=$ Nilai arah sebagai penentu ramalan (prediksi) yang menunjukkan nilai peningkatan (+) atau nilai penurunan (-) variabel Y

${ }^{18}$ Riduwan, Metode dan Teknik Menyusun Tesis, (Bandung: Alfabeta, 2004), h. 145-146.

$$
\begin{gathered}
\mathrm{b} \frac{\sum \mathrm{X} \cdot \mathrm{Y}-\sum \mathrm{X} \cdot \sum \mathrm{Y}}{\mathrm{n} \cdot \sum \mathrm{X}^{2}-\left(\sum \mathrm{X}\right)^{2}} \\
\mathrm{a}=\frac{\sum \mathrm{Y}-\mathrm{b} \cdot \sum \mathrm{X}}{\mathrm{n}}
\end{gathered}
$$

Langkah-langkah menjawab regresi sederhana:

Langkah 1 membuat $\mathrm{H}_{\mathrm{a}}$ dan $\mathrm{H}_{0}$ dalam bentuk kalimat.

Langkah 2 membuat $\mathrm{H}_{\mathrm{a}}$ dan $\mathrm{H}_{0}$ dalam bentuk statistik.

Langkah 3 membuat table penolong untuk menghitung angka statistik.

Langkah 4 masukkan angkaangka dari table penolong dengan rumus:

$$
\begin{gathered}
\mathrm{b} \frac{\sum \mathrm{X} \cdot \mathrm{Y}-\sum \mathrm{X} \cdot \sum \mathrm{Y}}{\mathrm{n} \cdot \sum \mathrm{X}^{2}-\left(\sum \mathrm{X}\right)^{2}} \\
\mathrm{a}=\frac{\sum \mathrm{Y}-\mathrm{b} \cdot \sum \mathrm{X}}{\mathrm{n}}
\end{gathered}
$$

Langkah 5 mencari jumlah kuadrat regresi $\left(\mathrm{JK}_{\mathrm{Reg}[\mathrm{a}]}\right)$ dengan rumus:

$$
\mathrm{JK}_{\mathrm{Reg}[\mathrm{a}]}=\frac{\left(\sum \mathrm{Y}\right)^{2}}{\mathrm{n}}
$$

Langkah 6 mencari jumlah kuadrat regresi $\left(J \mathrm{~K}_{\mathrm{Reg}(\mathrm{b} \mid \mathrm{a})}\right)$ dengan rumus:

$$
\mathrm{JK}_{\mathrm{Reg}(\mathrm{b} \mid \mathrm{a})}=\mathrm{b} \cdot\left\{\sum \mathrm{X} . \mathrm{Y}-\frac{\left(\sum \mathrm{X}\right) \cdot\left(\sum \mathrm{Y}\right)}{\mathrm{n}}\right\}
$$

Langkah 7 mencari jumlah kuadrat residu ( $\left(\mathrm{K}_{\mathrm{Res}}\right)$ dengan rumus:

$$
\mathrm{JK}_{\mathrm{Res}}=\sum \mathrm{Y}^{2}-\mathrm{JK}_{\mathrm{Reg}(\mathrm{b} \mid \mathrm{a})}-\mathrm{JK}_{\mathrm{Reg}[\mathrm{a}]}
$$

Langkah 8 mencari rata-rata jumlah kuadrat regresi $\left(\mathrm{RJK}_{\mathrm{Reg}[\mathrm{a}]}\right)$ dengan rumus:

$$
\mathrm{RJK}_{\mathrm{Reg}[\mathrm{a}]}=\mathrm{JK}_{\mathrm{Reg}[\mathrm{a}]}
$$

Langkah 9 mencari rata-rata jumlah kuadrat regresi $\left(\mathrm{JK}_{\mathrm{Reg}(\mathrm{b} \mid \mathrm{a})}\right)$ dengan rumus:

$$
\mathrm{RJK}_{\mathrm{Reg}(\mathrm{b} \mid \mathrm{a})}=\mathrm{JK}_{\mathrm{Reg}(\mathrm{b} \mid \mathrm{a})}
$$


Langkah 10 mencari rata-rata jumlah kuadrat residu $\quad\left(\mathrm{RJK}_{\mathrm{Res}}\right)$ dengan rumus:

$$
\mathrm{JK}_{\mathrm{Res}}=\frac{\mathrm{RJK}_{\mathrm{Res}}}{\mathrm{n}-2}
$$

Langkah 11 menguji signifikasi dengan rumus:

$$
\mathrm{F}_{\text {Hitung }}=\frac{J \mathrm{~K}_{\mathrm{Res}}(\mathrm{b} \mid \mathrm{a})}{\mathrm{RJK} \mathrm{K}_{\text {Res }}}
$$

Kaidah pengujian signifikasi: JikaF $F_{\text {Hitung }} \geq \mathrm{F}_{\text {Tabel }}$, maka tolakH $\mathrm{H}_{0}$ artinya signifikan, dan $\mathrm{F}_{\text {Hitung }} \leq \mathrm{F}_{\text {Tabel }}$, terima $\mathrm{H}_{0}$ artinya tidak signifikan. Adapun untuk mengetahui berpengaruh atau tidaknya penerapan Kurikulum 2013 terhadap kinerja guru, dianalisa dengan rumus:

Keterangan :

$$
\mathrm{P}=\frac{\mathrm{F}}{\mathrm{N}} \times 100 \%
$$

$\mathrm{P}=$ Angka Persentase

$\mathrm{F}=$ Frekuensi

$\mathrm{N}=$ Banyak Individu. ${ }^{19}$

\section{PEMBAHASAN}

Data dalam penelitian ini dilakukan dengan menggunakan teknik observasi. Observasi dilakukan sebanyak 9 (sembilan) kali untuk tiap variabel.

1. Penerapan Kurikulum 2013 (Variabel $\mathrm{X})$

Data hasil observasi tentang penerapan Kurikulum 2013 Pendidikan Agama Islam kelas IV (Variabel X), Rekapitulasi hasil observasiyang ditunjukkan tabel adalah 147 kali ya $(68,06 \%)$ dan 69 kali tidak $(31,94 \%)$, dengan jumlah total 216 (100\%).

${ }^{19}$ Anas Sudijono, Pengantar Statistik Pendidikan, (Jakarta: Raja Grafindo Persada, 2008), h. 43.
Selanjutnya hasil observasi ya diberi skor 1 dan hasil observasi tidak diberi skor $0 .{ }^{20}$ Maka didapat hasil:

$$
\begin{array}{ll}
\text { ya } & =147 \times 1=147 \\
\text { Tidak } & =69 \times 0=0 \\
\text { Jumlah Total } & =147
\end{array}
$$

Maka, $\mathrm{F}=147$, dan $\mathrm{N}=$ Jumlah Populasi x Jumlah

Aspek Yang Diobservasi x Jumlah Observasi $x$ Skor Tertinggi

$$
=1 \times 24 \times 9 \times 1=
$$

Penerapan Kurikulum 2013 Pendidikan Agama Islam, digunakan rumus:

$$
\begin{aligned}
\mathrm{P} & =\frac{\mathrm{F}}{\mathrm{N}} \times 100 \% \\
& =\frac{147}{216} \times 100 \%=68,06 \%
\end{aligned}
$$

Penerapan Kurikulum 2013 Pendidikan Agama Islam, mencapai angka $68,06 \%$ dan dikategorikan baik, karena angka 68,06\% terletak pada interval $61 \%-80 \%$.

2. Pembahasan Data Hasil Observasi (Variabel Y)

Pembahasan terhadap data variabel Y dilakukan dengan cara membuat rekapitulasi sebagai berikut:

Rekapitulasi hasil observasi yang ditunjukkan tabel adalah 156 kali ya $(72,22 \%)$ dan 60 kali tidak $(27,78 \%)$, dengan jumlah total 216 (100\%). Selanjutnya hasil observasi "ya" diberi skor 1 dan hasil observasi tidak diberi skor $0 .{ }^{21}$ Maka didapat hasil:

$$
\begin{aligned}
& \text { Ya = } 156 \times 1=156 \\
& \text { Tidak =60 × } 0=0 \\
& \text { Jumlah Total }=156
\end{aligned}
$$

${ }^{20}$ Riduwan, Belajar Mudah Penelitian Untuk Guru, Karyawan, dan Peneliti Pemula, (Bandung: Alfabeta, 2004), h. 91.

${ }^{21}$ Ibid., h. 91. 
Maka, $\mathrm{F}=156$, dan $\mathrm{N}=$ Jumlah Populasi $\mathrm{x}$ Jumlah Aspek Yang Diobservasi x Jumlah Observasi x Skor Tertinggi

$$
=1 \times 24 \times 9 \times 1=216
$$

Kinerja guru Pendidikan Agama Islam, digunakan rumus:

$$
\begin{aligned}
P & =\frac{\mathrm{F}}{\mathrm{N}} \times 100 \% \\
& =\frac{156}{216} \times 100 \%=72,22 \%
\end{aligned}
$$

Kinerja guru Pendidikan Agama Islam, mencapai angka $72,22 \%$ dan dikategorikan baik, karena angka $69,44 \%$ terletak pada interval $61 \%$ $80 \%$.

3. Pengaruh Penerapan Kurikulum 2013 terhadap Kinerja Guru Pendidikan Agama Islam.

\section{Langkah Pertama:}

Membuat $\mathrm{H}_{\mathrm{a}}$ dan $\mathrm{H}_{\mathrm{o}}$ dalam bentuk kalimat di bawah ini:

$\mathrm{H}_{\mathrm{a}}$ : Terdapat pengaruh yang positif dan signifikan antara penerapan Kurikulum 2013 terhadap kinerja guru Pendidikan Agama Islam.

$\mathrm{H}_{\mathrm{o}}$ : Tidak terdapat pengaruh yang positif dan signifikan antara penerapan Kuri- kulum 2013 terhadap kinerja guru Pendidikan Agama.

\section{Langkah Kedua:}

Membuat $\mathrm{H}_{\mathrm{a}}$ dan $\mathrm{H}_{\mathrm{o}}$ dalam bentuk statistik, yaitu:

$$
\begin{aligned}
& \mathrm{H}_{\mathrm{a}}: \mathrm{r} \neq 0 \\
& \mathrm{H}_{\mathrm{o}}: \mathrm{r}=0
\end{aligned}
$$

\section{Langkah ketiga:}

Membuat tabel penolong untuk menghitung angka statistik dengan cara sebagai berikut:

\begin{tabular}{|c|l|l|l|}
\hline$\sum \mathbf{y}=$ & $\sum \mathbf{X}^{\mathbf{2}}=$ & $\sum \mathbf{Y}^{\mathbf{2}}=$ & $\sum \mathbf{X . y}=$ \\
$\mathbf{1 5 6}$ & $\mathbf{2 4 3 5}$ & $\mathbf{2 8 2 0}$ & $\mathbf{2 5 9 8}$ \\
\hline
\end{tabular}

\section{Langkah Keempat:}

Memasukkan angka-angka statistik dari tabel penolong kedalam rumus:

a. Menghitung rumus $b$

$$
\begin{aligned}
\mathrm{b} & =\frac{\sum \mathrm{X} \cdot \mathrm{Y}-\sum \mathrm{X} \cdot \sum \mathrm{Y}}{\mathrm{n} \cdot \sum \mathrm{X}^{2}-\left(\sum \mathrm{X}\right)^{2}} \\
\mathrm{~b} & =\frac{2598-147 \cdot 156}{1 \cdot 2435-(147)^{2}} \\
\mathrm{~b} & =\frac{2598-22932}{2435-21609} \\
\mathrm{~b} & =\frac{-20334}{-19174}=1,06
\end{aligned}
$$

Dengan demikian diketahui bahwa nilai $b=1,06$

b. Menghitung rumus a

$$
\begin{aligned}
& a=\frac{\sum Y-b \cdot \sum X}{n} \\
& a=\frac{156-1,06 \cdot 147}{1} \\
& a=\frac{156-155,82}{1} \\
& a=\frac{0,18}{1}=0,18
\end{aligned}
$$

Dengan demikian diketahui bahwa nilai $\mathrm{a}=0,18$

c. Menghitung persamaan regresi sederhana

$$
\begin{aligned}
\hat{\mathrm{Y}} & =\mathrm{a}+\mathrm{b} \mathrm{X} \\
& =0,18+1,06(\mathrm{X})
\end{aligned}
$$

d. Membuat garis persamaan regresi

1) Menghitung rata-rata $X$ dengan rumus

$$
\begin{aligned}
& X=\frac{\sum X}{n} \\
& X=\frac{147}{1}=147
\end{aligned}
$$

2) Menghitung rata-rata $Y$ dengan rumus

$$
\begin{aligned}
& Y=\frac{\sum Y}{n} \\
& Y=\frac{156}{1}=156
\end{aligned}
$$




\section{Langkah Kelima}

Mencari jumlah kuadrat regresi $\left(\mathrm{JK}_{\mathrm{Reg}[\mathrm{a}]}\right)$ dengan rumus:

$$
\begin{aligned}
\mathrm{JK}_{\text {Reg[a] }} & =\frac{\left(\sum \mathrm{Y}\right)^{2}}{\mathrm{n}} \\
\mathrm{JK}_{\text {Reg[a] }} & =\frac{(156)^{2}}{1} \\
\mathrm{JK}_{\text {Reg[a] }} & =\frac{24336}{1}=24336
\end{aligned}
$$

\section{Langkah Keenam}

Mencari jumlah kuadrat regresi $\left(\mathrm{JK}_{\mathrm{Reg}(\mathrm{b} \mid \mathrm{a})}\right)$ dengan rumus:

$$
\begin{aligned}
& \mathrm{JK}_{\mathrm{Reg}(\mathrm{b} \mid \mathrm{a})}=\mathrm{b} \cdot\left\{\sum \mathrm{XY}-\frac{\left(\sum \mathrm{X}\right) \cdot\left(\sum \mathrm{Y}\right)}{\mathrm{n}}\right\} \\
& \mathrm{JK}_{\mathrm{Reg}(\mathrm{b} \mid \mathrm{a})}=1,06 \cdot\left\{2598-\frac{(147) \cdot(156)}{1}\right\}
\end{aligned}
$$$$
\mathrm{JK}_{\mathrm{Reg}(\mathrm{b} \mid \mathrm{a})}=1,06 \cdot\left\{2598-\frac{22932}{1}\right\}
$$$$
J_{\mathrm{Reg}(b \mid a)}=1,06 .\{2598-22932\}
$$$$
\mathrm{JK}_{\mathrm{Reg}(\mathrm{b} \mid \mathrm{a})}=1,06 \cdot\{-20334\}
$$$$
\mathrm{JK}_{\mathrm{Reg}(\mathrm{b} \mid \mathrm{a})}=-21554,04
$$

\section{Langkah Ketujuh}

Mencari jumlah kuadrat residu $\left(\mathrm{JK}_{\mathrm{Res}}\right)$ dengan rumus:

$$
\begin{aligned}
& \mathrm{JK}_{\text {Res }}=\sum \mathrm{Y}^{2}-\mathrm{JK}_{\mathrm{Reg}(\mathrm{b} \mid \mathrm{a})}-\mathrm{JK}_{\mathrm{Reg}[\mathrm{a}]} \\
& \mathrm{JK}_{\text {Res }}=2820-(-21554,04)-24336 \\
& \mathrm{JK}_{\text {Res }}=38,04
\end{aligned}
$$

\section{$>$ Langkah Kedelapan}

Mencari rata-rata jumlah kuadrat regresi $\left(\mathrm{RJK} \mathrm{K}_{\mathrm{Reg}[\mathrm{a}]}\right)$ dengan rumus:

$$
\begin{aligned}
\mathrm{RJK}_{\text {Reg[a] }} & =J K_{\text {Reg[a] }} \\
\mathrm{RJK}_{\text {Reg[a] }} & =24336
\end{aligned}
$$

\section{Langkah Kesembilan}

Mencari rata-rata jumlah kuadrat regresi $\left(\mathrm{RJK} \mathrm{K}_{\operatorname{Reg}(\mathrm{b} \mid \mathrm{a})}\right)$ dengan rumus:

$$
\begin{aligned}
& \mathrm{RJK}_{\operatorname{Reg}(b \mid a)}=J_{\operatorname{Reg}(b \mid a)} \\
& \operatorname{RJK}_{\operatorname{Reg}(b \mid a)}=-21554,04
\end{aligned}
$$

\section{Langkah Kesepuluh}

Mencari rata-rata jumlah kuadrat residu $\left(\mathrm{RJK}_{\mathrm{Res}}\right)$ dengan rumus:

$$
\begin{aligned}
\mathrm{RJK}_{\mathrm{Res}} & =\frac{J K_{\mathrm{Res}}}{\mathrm{n}-2} \\
\mathrm{RJK}_{\mathrm{Res}} & =\frac{38,04}{1-2} \\
\mathrm{RJK}_{\mathrm{Res}} & =\frac{38,04}{-1} \\
\mathrm{RJK}_{\mathrm{Res}} & =-38,04
\end{aligned}
$$

\section{Langkah Kesebelas}

Menguji signifikansi dengan rumus:

$$
\begin{aligned}
& F_{\text {hitung }}=\frac{\mathrm{RJK}_{\mathrm{Res}(\mathrm{b} \mid \mathrm{a})}}{\mathrm{RJK}_{\mathrm{Res}}} \\
& \mathrm{F}_{\text {hitung }}=\frac{-21554,04}{-38,04} \\
& \mathrm{~F}_{\text {hitung }}=566,62
\end{aligned}
$$

Kaidah pengujian signifikasi:

Jika $F_{\text {hitung }} \geq \mathrm{F}_{\text {tabel }}$, maka tolak $\mathrm{H}_{\mathrm{o}}$ artinya signifikan, dan

$\mathrm{F}_{\text {hitung }} \leq \mathrm{F}_{\text {tabel }}$, terima $\mathrm{H}_{\mathrm{o}}$ artinya tidak signifikan

Dengan taraf signifikan $(\alpha)=0,05$

Carilah nilai $\mathrm{F}_{\text {tabel }}$ menggunakan tabel $\mathrm{F}$ dengan rumus:

$\mathrm{F}_{\text {tabel }}=\mathrm{F}(1-\alpha)\{(\mathrm{dkReg}(\mathrm{b} \mid \mathrm{a}),(\mathrm{dkRes})\}=$ F $(1-0,05)\{(\operatorname{dkReg}(b \mid a)=1,(d k R e s)=1-2=-$ 1)\}

$$
\begin{aligned}
& =\mathrm{F}(0,95)\{1,(-1)\} \\
& \mathrm{F}_{\text {tabel }}=\text { angka } 1=\text { pembilang angka } \\
& -1=\text { penyebut } \\
& \mathrm{F}_{\text {tabel }}=-161
\end{aligned}
$$

Ternyata $F_{\text {hitung }} \geq F_{\text {tabel }}$, maka tolak $\mathrm{H}_{\mathrm{o}}$, artinyasignifikan.

\section{Langkah Keduabelas}

Membuat Kesimpulan

Karena $F_{\text {hitung }} \geq F_{\text {tabel }}$, maka tolak $\mathrm{H}_{\mathrm{o}}$ dan terima $\mathrm{H}_{\mathrm{a}}$. Dengan demikian terdapat pengaruh yang positif dan signifikan antara penerapan Kurikulum 2013 terhadap kinerja guru Pendidikan Agama Islam. 


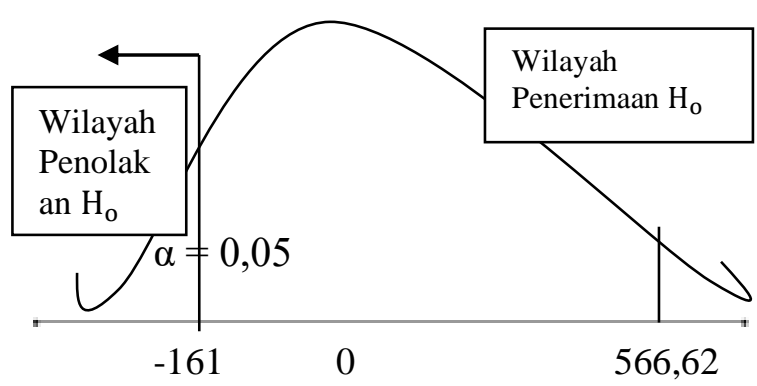

Berdasarkan pembahasan data melalui observasi dapat dilakukan analisa sebagai berikut:

Melalui analisa data pada variabel X, yaitu penerapan Kurikulum 2013, mencapai angka $68,06 \%$ dan dikategorikan baik, karena angka $68,06 \%$ terletak pada interval $61 \%$ $80 \%$.

Melalui analisa data pada variabel Y, yaitu kinerja guru Pendidikan Agama Islam, mencapai angka $72,22 \%$ dan dikategorikan baik, karena angka $72,22 \%$ terletak pada interval $61 \%$ $80 \%$.

Melalui analisa data terhadap kedua variabel di atas didapat hasil $\mathrm{F}_{\text {hitung }} \geq \mathrm{F}_{\text {tabel }}$ maka tolak $\mathrm{H}_{\mathrm{o}}$ dan terima $\mathrm{H}_{\mathrm{a}}$. Dengan demikian terdapat pengaruh yang positif dan signifikan antara penerapan Kurikulum 2013 terhadap kinerja guru Pendidikan Agama Islam.

\section{KESIMPULAN}

Berdasarkan hasil analisa data melaluiobservasi pada variabel $X$ danvariabel Y dapat disimpulkan sebagai berikut:

1. Penerapan Kurikulum 2013 Pendidikan Agama Islam, mencapai angka $68,06 \%$ dan dikategorikan baik, karena angka 68,06\% terletak pada interval $61 \%-80 \%$.
2. Kinerja guru Pendidikan Agama Islam, mencapai angka $72,22 \%$ dan dikategorikan baik, karena angka $72,22 \%$ terletak pada interval $61 \%$ $80 \%$.

3. Terdapat pengaruh yang positif dan signifikan antara penerapan Kurikulum 2013 terhadap kinerja guru Pendidikan Agama Islam.

\section{REFERENSI}

A.Tabrani Rusyan dan Wasmin. (2008). Etos kerja dalam Meningkatkan Produktivitas Kinerja Guru. Jakarta: PT. Intimedia Ciptanusantara.

Ahmad Yani. (2013). Mindset Kurikulum 2013. Bandung: Alfabeta.

Anas Sudijono. (2008). Pengantar Statistik Pendidikan. Jakarta: Raja Grafindo Persada.

Andi Prastowo. (2013). Pengembangan Bahan Ajar Tematik. Jogjakarta: Diva Pers.

Burhan Bungin. (2010). Metodologi Penelitian Pendidikan Kualitatif. Jakarta: Raja Grafindo.

Cholid Narbuko dan Abu Ahmad. (2005). Metodologi Penelitian. Jakarta: Bumi Aksara.

E. Mulyasa. (2007). Standar Kompetensi dan Sertifikasi Guru. Bandung: Remaja Rosdakarya.

Imas Kurniasih dan Berlin Sani. (2016). Revisi Kurikulum 2013. Jakarta: Kata Pena.

Iskandar. (2010). Metodologi Penelitian Pendidikan. Jakarta: Gaung Persada Press.

Kunandar. (2008). Guru Profesional; Implementasi KTSP dan Sukses dalam Sertifikasi Guru. Jakarta: Raja Grafindo Persada.

Lukmanul Hakim. (2008). Perencanaan Pembelajaran. Bandung: Wacana Prima. 
M. Musfiqon. (2012). Panduan Lengkap Metodologi Penelitian Pendidikan. Jakarta: Prestasi Pustakaraya.

Martinis Yamin. (2006). Sertifikasi Profesi Keguruan di Indonesia. Jakarta: Gaung Persada Press.

Martinis Yamin dan Maisah. (2010). Standarisasi Kinerja Guru. Jakarta: Gaung Persada Press.

Muhibbin Syah. (2008). Psikologi Pendidikan dengan Pendekatan Baru. Bandung: Remaja Rosdakarya.

Pius Abdillah dan Danu Prasetya. (2002). Kamus Bahasa Indonesia. Surabaya: Arkola.

Riduwan. (2004). Metode dan Teknik Menyusun Tesis. Bandung: Alfabeta. (2002). Skala Pengukuran Variabel-Variabel Penelitian. Bandung: Alfabeta.

Rusman. (2016). Model-Model Pembelajaran Pengembangan Profesional Guru. Jakarta: Raja Grafindo Persada.

Sofan Amri. (2013). Pengembangan dan Model Pembelajaran dalam Kurikulum 2013. Jakarta: Prestasi Pustakaraya.

Sukardi. (2005). Metodologi Penelitian Pendidikan. Jakarta: Bumi Aksara.

Syaiful Bahri Djamarah dan Aswan Zain. (2006). Strategi Belajar Mengajar. Jakarta: Rineka Cipta.

Tim Penyusun Kemendikbud. (2013). Dokumen Kurikulum 2013 Kompetensi Dasar SD/MI. Jakarta: Kemendikbud.

Tim Pustaka Yustisia. (2008). Panduan Lengkap KTSP. Yogyakarta: Pustaka Yustisia.

Tim Reality. (2008). Kamus Bahasa Indonesia. Surabaya: Reality Publisher.

Trianto. (2008). Mengembangkan Model Pembelajaran Tematik. Jakarta: Prestasi Pustaka Publisher.
Undang-Undang Nomor 20 Tahun 2003 tentang Sistem Pendidikan Nasional.

Wardiman Djoyonegoro. (2000). Peningkatan kualitas Melalui Pendidikan dan kebudayaan. Jakarta: Depdikbud.

Widodo. (2004). Cerdik Menyusun Proposal Penelitian. Jakarta: Yayasan Kelompok. 